\title{
Yasmine Elmajzoub
}

\section{Beirut Heritage Initiative: Safeguarding the City's Built Heritage After the August 4, 2020, Port Explosion}

\author{
Beirut Heritage Initiative: Salvaguardar el \\ patrimonio construido de la ciudad tras la explosión \\ del puerto el 4 de agosto de 2020 \\ Beirut Heritage Initiative: Salvaguardar o \\ património construído da cidade após a explosão \\ portuária de 4 de Agosto de 2020
}

\begin{abstract}
Resumen | Resumo
The devastating explosion in Beirut's port on August 4, 2020 will forever be engraved in the memory of the Lebanese people. Within moments, a city with over 5,000 years of history was in ruins. Aside from the terrible casualties, the blast impacted one of the largest concentrations of heritage buildings in the city, dating from the 19th and 20th centuries. For this reason Beirut Heritage Initiative (BHI) was established in an attempt to help restore the city's built heritage and to preserve both the urban and the social fabric of the damaged neighborhoods. BHI's first mission was focused on emergency works such as rapid sheltering and consolidation of damaged buildings to prevent further damage due to the winter weather. After this emergency phase, BHI has engaged in partial reconstructions to enable vulnerable inhabitants to return to their homes, and a third phase has focused on full restoration projects for highly damaged buildings.
\end{abstract}

La devastadora explosión del puerto de Beirut el 4 de agosto de 2020 quedará grabada para siempre en el recuerdo de los libaneses. En unos minutos, una ciudad de más de 5000 años de historia se convertía en ruinas. Aparte de la enorme cantidad de víctimas mortales y heridos, la explosión había afectado a una de las mayores concentraciones de edificios históricos de la ciudad, que databan de los siglos XIX y XX. A partir de ahí nació la Beirut Heritage Initiative (BHI) con el fin de intentar ayudar a restaurar el patrimonio construido de Beirut y conservar el tejido urbano y social de los barrios asolados. La primera misión de BHI se centró en las obras más urgentes, como proteger y consolidar rápidamente los edificios dañados para evitar mayores destrozos durante las tormentas invernales. Tras la fase de emergencia, BHI participó en reconstrucciones parciales que permitieran a los habitantes vulnerables regresar a sus hogares, mientras que la tercera fase de la intervención se ha centrado en proyectos de restauración integral de edificios muy dañados.

A explosão devastadora do porto de Beirute, a 4 de Agosto de 2020, ficará para sempre gravada na mente do povo Libanês. Em poucos minutos, a cidade com mais de 5.000 anos de história estava em ruínas. Para além do arrebatador número de mortos e feridos, a explosão tinha visado uma das maiores concentrações de edifícios históricos da cidade, que remontam aos séculos XIX e XX. Foi por esse motivo que a Beirut Heritage Initiative (BHI) nasceu, na tentativa de ajudar a restaurar o património construído da cidade e de preservar tanto o tecido urbano como social dos bairros desolados. A primeira missão da BHI centrou-se em obras de emergência, tais como a criação rápida de abrigos e a consolidação dos edifícios danificados, para evitar danos subsequentes durante as tempestades de inverno. Após a fase de emergência, a BHI participou em reconstruções parciais que permitiriam aos habitantes vulneráveis regressar às suas casas, enquanto que a terceira fase de intervenção se centrou em projectos de restauração integral de edifícios altamente danificados. 


\section{Introduction}

Said to be the third-largest non-nuclear blast in world history, the Beirut port explosion killed more than 200 people and injured over 6,500 others. More than 60,000 offices and homes were destroyed, displacing over 100,000 people.

Heritage buildings suffered their share of destruction as nearly 1,000 houses, apartment buildings, and mansions of the 19th-century Ottoman period, and modern heritage buildings of the 1930s-70s were ravaged.

The neighborhoods most affected, such as Gemmayzeh, Mar Mikhael, and Ashrafieh, that have the highest concentration of built heritage, are home to people from different cultural and social backgrounds. With their cultural, educational, touristic, and artisanal facilities, these neighborhoods contribute much to Beirut's intangible heritage.

1: Map of the damages of the Beirut explosion (NASA)

2: BHI Beirut Map projects (Yasmine Dagher)
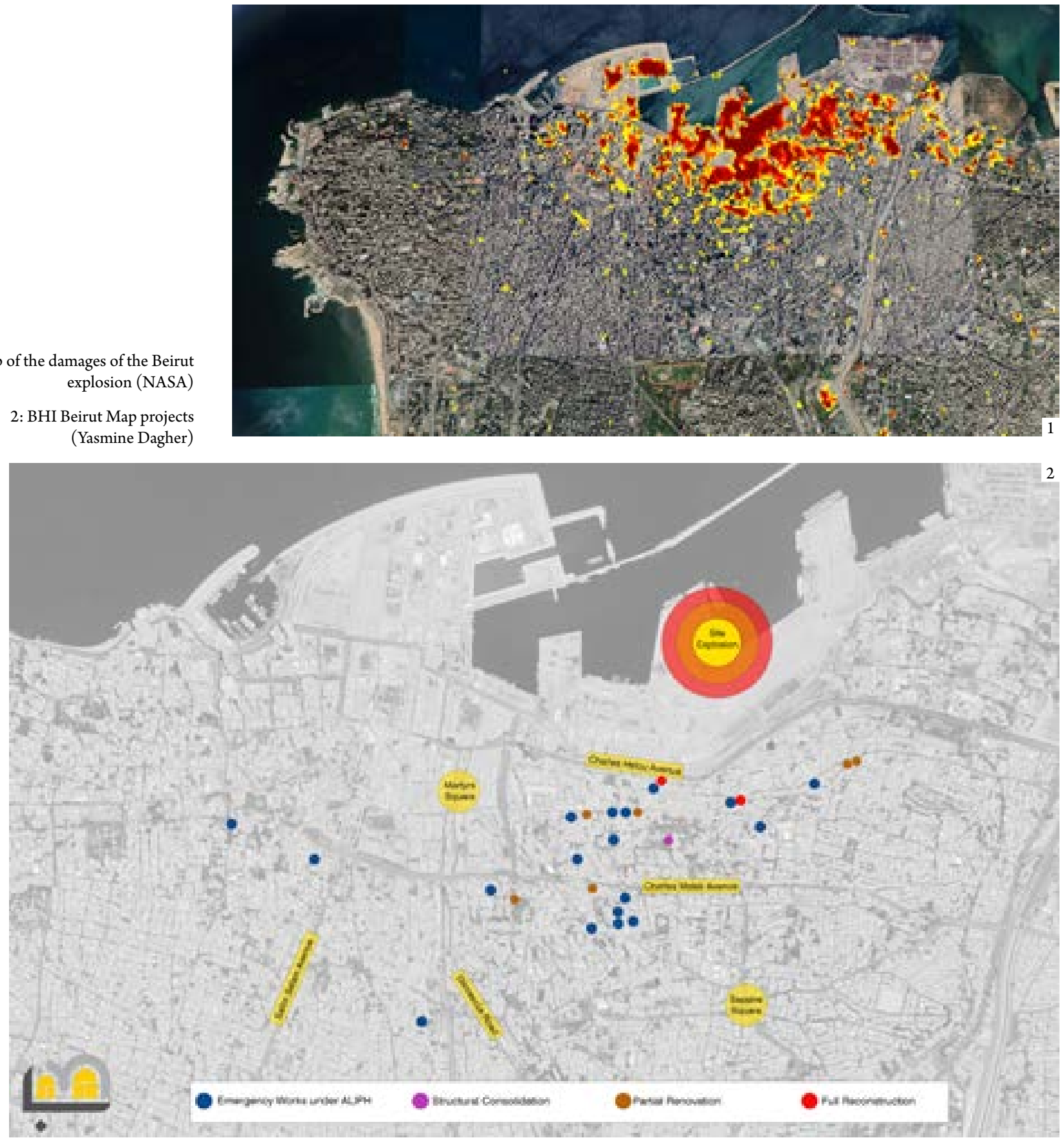


\section{BHI's mission and objectives}

Beirut Heritage Initiative (BHI) was launched a few days after the port explosion as an independent and inclusive collective for assisting in the restoration of Beirut's destroyed built and cultural heritage. Organized around a team of experts, professionals, and NGOs specialized in cultural heritage and with complementary skills, BHI took on the role of mediator between the residents of affected homes and official bodies to facilitate the issuing of restoration and reconstruction permits from the Directorate General of Antiquities and the Office of the Governor of Beirut.

What remained of Beirut's built heritage from the 19th and 20th centuries was what had stood the test of time and survived the voracity of real estate developers. After the blast, Beiruti residents and community became more aware of the importance of rescuing their built heritage, as it plays a significant role in preserving our city's historical and cultural identity. BHI's mission thus focuses on the protection of this heritage and Beirut's socio-economic fabric. It seeks a sustainable revitalization of the damaged neighborhoods with the highest concentration of heritage clusters, including Ottoman stone and red-tile houses, French Mandate buildings, and early Modernist apartment blocks.

\section{Building typology, materials, and key features}

The Lebanese vernacular home has undergone several stages of evolution. A typical traditional Beiruti building of the 19th-century Ottoman period revolves around a central hall oriented to the north. Its layout allows for natural cross ventilation and adequate lighting of interior spaces. The central hall acts as the main circulation area with various rooms on the east and west sides. Amenities such as the kitchen and bathrooms were integrated during this period into the floor plan, with the kitchen being covered with a stone vault to mitigate fire hazards. Typically, at the northern end of the central hall is framed by a triple arch that opens up to a Carrara marble balcony mounted by wrought iron balustrades imported from Great Britain or France and held over limestone corbels or wooden beams with metallic trusses. We also find that the central hall is separated from the liwan, the room located at the southern side of the house, by a set of internal triple arches.

These houses are built of sandstone (ramli) quarried from the city's outskirts and the bearing walls are either left bare or plastered with lime render. The sloping roofs of these buildings are constructed from Cedrus libani beams imported from Turkey and locally known as qotrani wood. These complex pyramidal truss systems are topped with red clay tiles imported from Marseille, France.

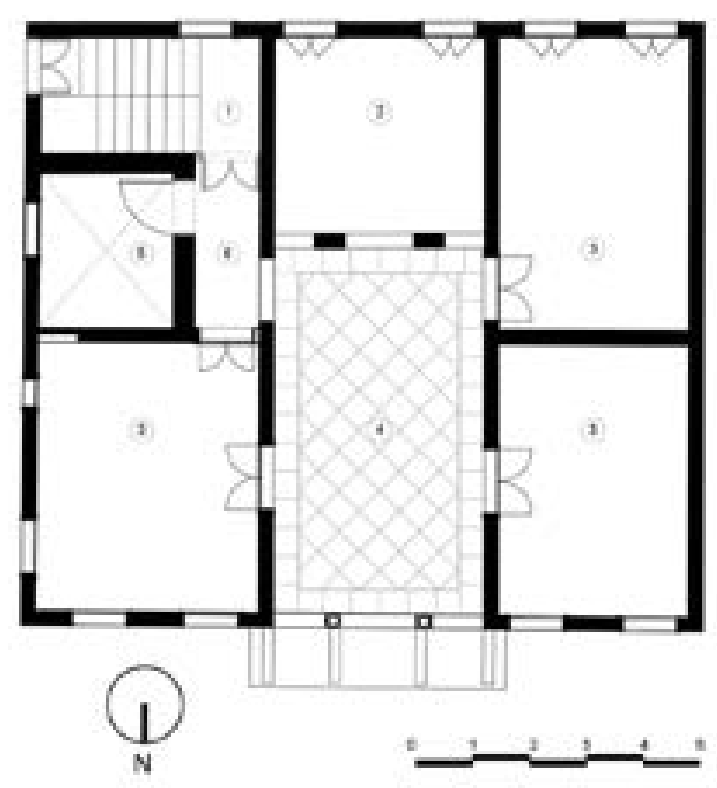

Plan of the typology (Maroun Khadra)

Legend: 1 Staircase, 2 Liwan, 3 Multipurpose room, 4 Central hall, 5 Kitchen, 6 Entrance 
The first-floor ceilings are typically made of Cedrus libani beams and joists covered by wooden planks. The upper-floor ceiling under the pitched roof is referred to as a Baghdadi ceiling and is made of thin wooden latticework plastered with lime and gypsum. The Baghdadi ceilings of mansions and upper-class homes have lavishly decorated cornices and reliefs with hand-painted frescoes and a central medallion over a hanging chandelier. As for the windows, doors, and shutters, they are all made of cedar (qotrani).

As to floor finishes, the tiles widely used for the central hall and liwan are of Carrara marble from Italy. In more elaborate houses, marble tiles are framed by black basalt strips and belts creating an elegant contrast with the white marble. The remaining rooms tend to have a limecrete render, locally known as adseh, consisting of lime, sand, pebbles, and water. Once it is polished with a smooth river stone to reveal the colored pebbles, it is then sealed with a thin layer of olive oil soap for a smooth waterproof finish. Limecrete was later replaced by colorful patterned cement tiles or red terracotta. Kitchen floors were finished with limestone furni tiles known for their strength and durability.

During the French mandate in the 1920s, the central hall plan persisted with a few modifications including the early use of concrete. After Lebanon's independence in 1943, the typology of houses began to change as the separation of private and common areas within them through transitional spaces and corridors became more evident. Around the same time, the symmetry of traditional houses was abandoned and floor plans and also facades became often asymmetrical. As of the mid-1950s, the international style was introduced into Lebanese architecture and new zoning and building laws reframed the types and esthetics of Beiruti houses.

After the introduction of concrete in the 1930s, the use of sandstone gradually receded. Modern heritage buildings built between 1940 and 1970 were constructed entirely of concrete with additional floors. Window frames and shutters were made of either wood or metal and wall finishes ranged from plain cement plaster to Tyrolian or Kratz plaster. As for floor finishes, cement tiles with colorful geometric patterns were adopted in interiors, with designs that gradually became more minimalistic.

: Reconstruction of the king post

3: Reconstruction of the timber frame

4: Installation of the red clay tiles
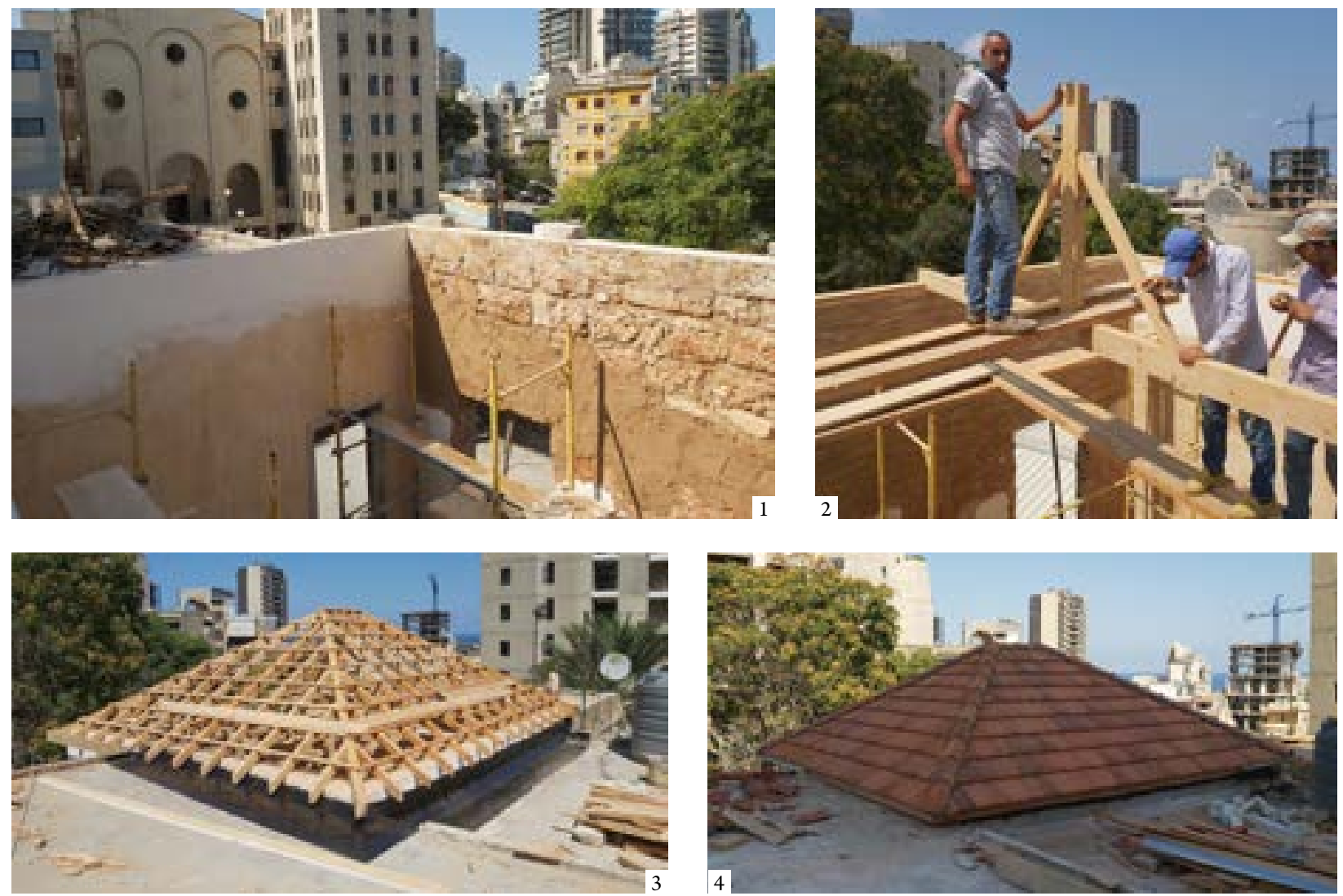


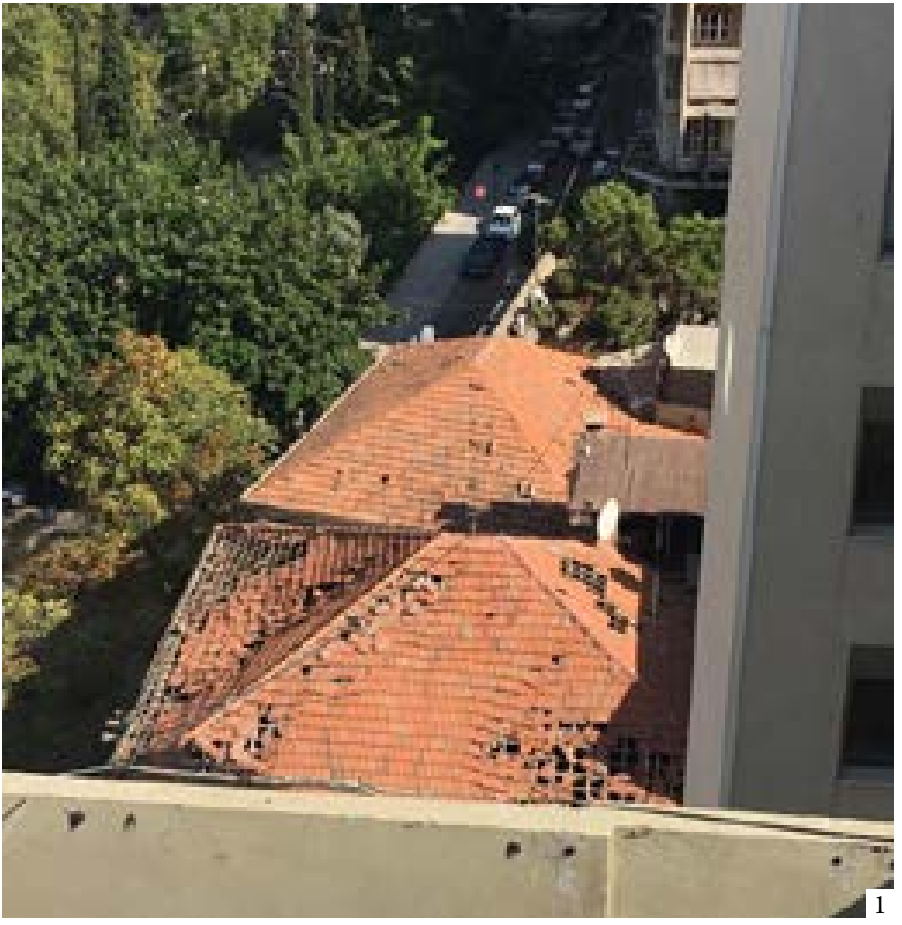

\section{Emergency sheltering and shoring work}

Shortly after the blast, BHI received a grant from the International Alliance for the Protection of Heritage in Conflict Areas (ALIPH) to conduct emergency shoring and sheltering work. In coordination with the Directorate General of Antiquities (DGA) and Beirut Built Heritage Rescue (BBHR20), BHI executed twenty-two interventions on nineteen heritage buildings.

Our sheltering interventions varied according to the degree of roof damage. For example, where the damage was confined to broken red clay tiles on a pitched roof, they involved replacing tiles. If the wooden beams and rafters of a pitched roof were severely damaged, a temporary tarpaulin cover was installed to protect the remaining structure. As to modern heritage buildings of the 1930s-60s with reinforced concrete roofing, the intervention involved repairing damaged screed and waterproofing layers.

Finally, two of the pitched roofs previously covered with tarpaulin and an additional small roof are being fully rebuilt under the same grant.
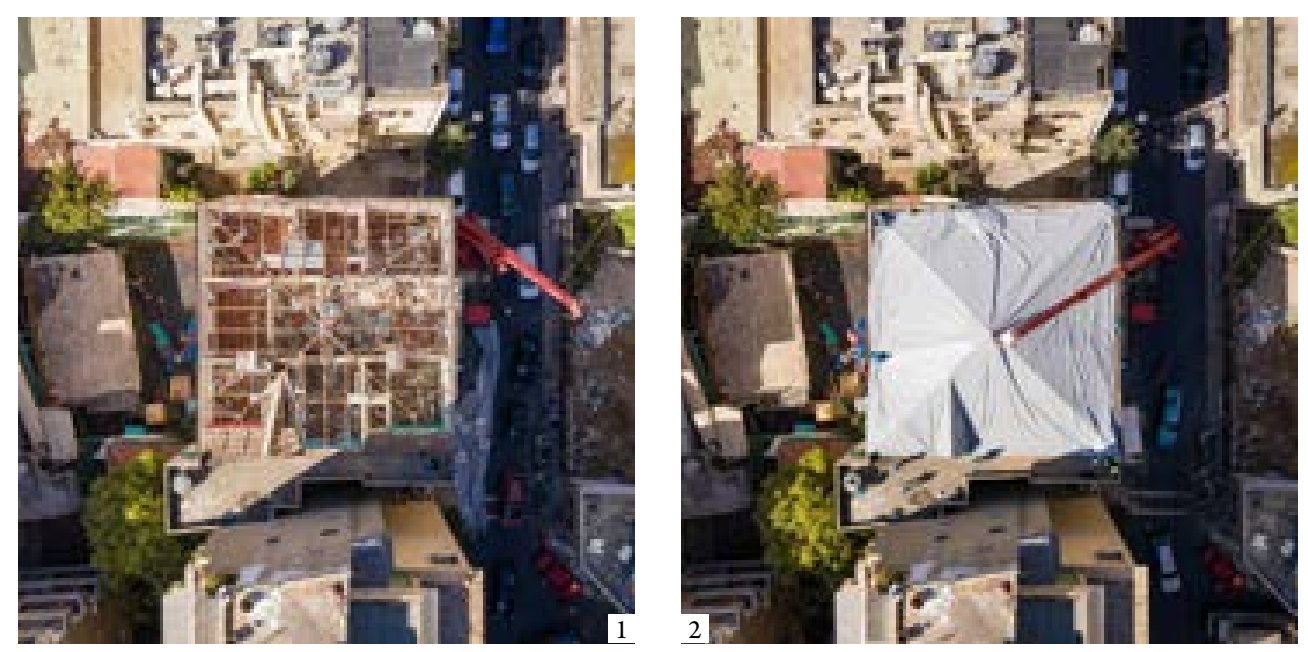

1: Top view of the destroyed pitched roof

2: Covering of the pitched roof with temporary tarpaulin

3: Sheltered roof and triple arched bay

(1, 2: Live Love Beirut (LLB) 3: Dia Mrad)

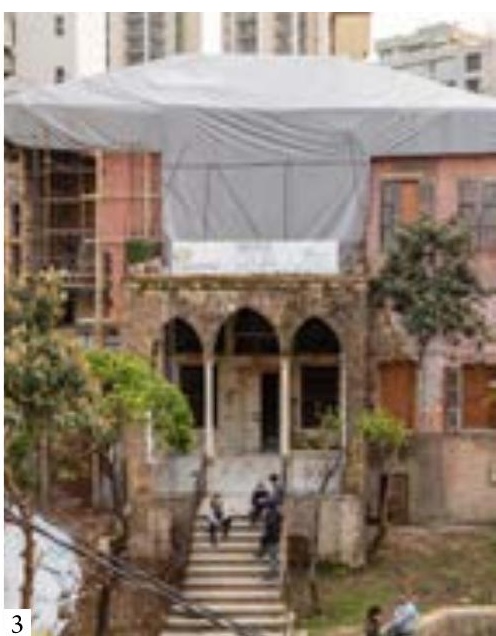




\section{Reconstruction of iconic triple-arched windows}

As mentioned earlier, the triple-arched bay is an iconic feature of a traditional Beiruti building. Since this feature is usually located on the building's northern façade, which faces the port and the sea, it was one of the first elements to be wrecked by the explosion. The destruction of these arches left the interior of houses exposed and their structure vulnerable.

BHI was able to restore this unique architectural feature in two heritage buildings. The first step was to rebuild the sandstone parapets and Carrara marble columns with their capitals. Then the damaged limestone corbels or wooden beams supporting the $4 \mathrm{~cm}$ thick Carrara marble balcony slab were restored and wrought iron balustrades installed. Then the sandstone arches were reconstructed with the help of wooden molds to ensure that the measurements were precise. Finally the parapets were plastered with lime.

: Sorting of the salvage arches' sandstones (Dia Mrad)

5: The reconstructed triple arches and Carrara marble balcony

(Yasmine Elmajzoub)
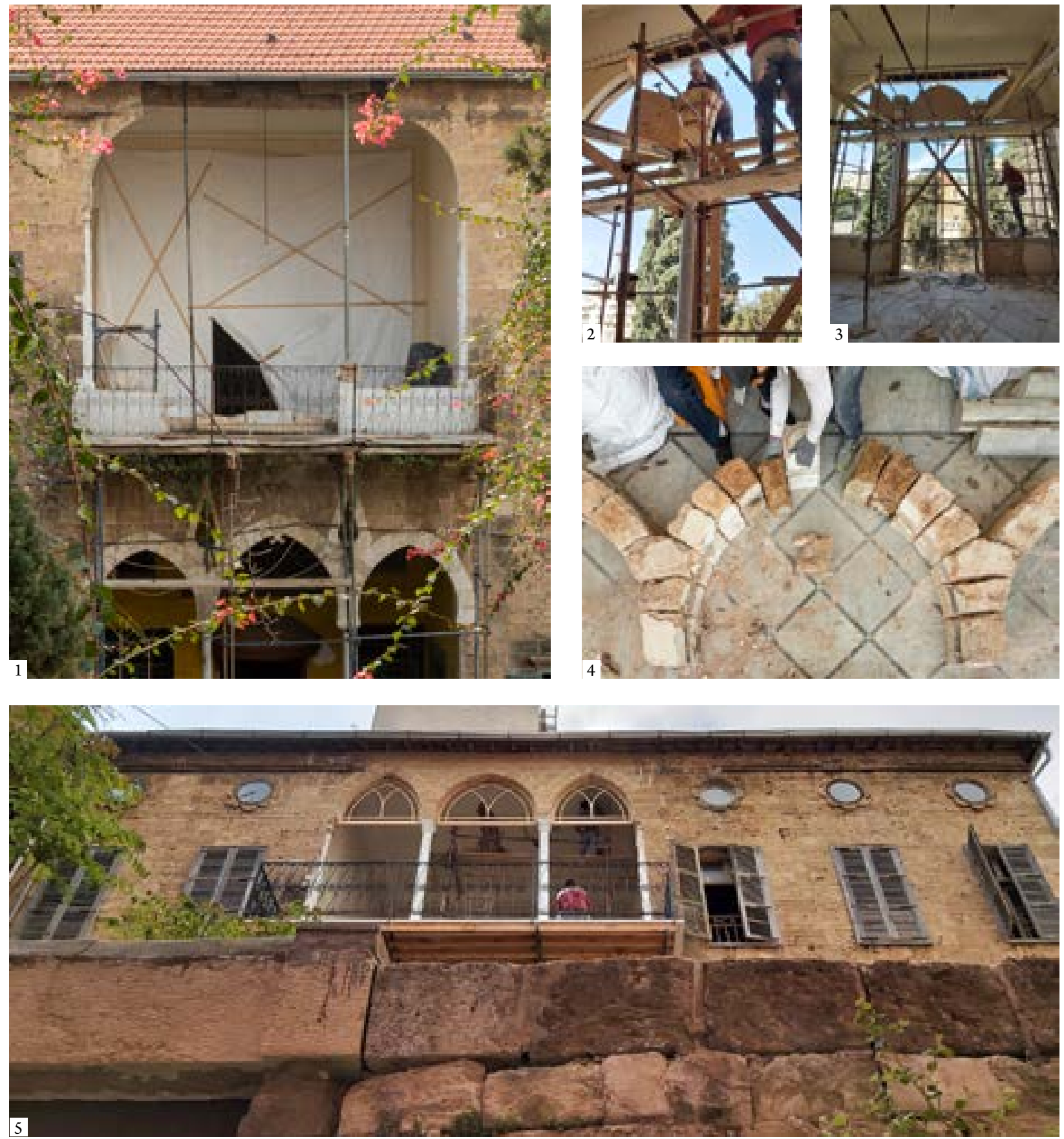


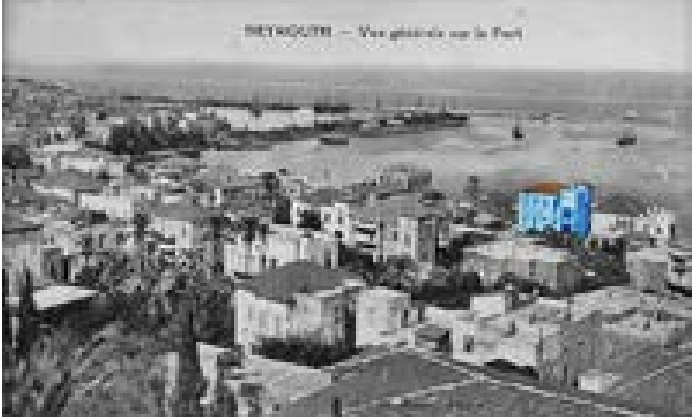

\section{Full renovations in heritage clusters}

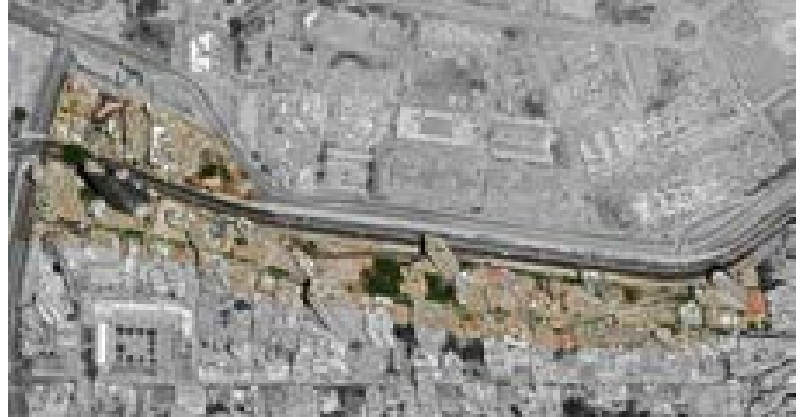

1: Medawar Shoreline 1890 (Beirut Heritage Facebook page) 2: Shoreline Cluster (Yasmine Dagher)

For optimal impact in maintaining the city's social and urban fabric, BHI adopted a "cluster strategy" aimed at forming partnerships with other NGOs for restoring sets of heritage buildings within a cluster rather than individual structures. This strategy allows the inhabitants of the cluster to return, bringing it back to life.

\section{The Shoreline Cluster}

Before the construction of Charles Helou Avenue and the port's expansion in the 1960s, the buildings within this cluster stood on the abrupt shorefront of Medawar, overlooking the bay of St. Andrew. Today the cluster includes thirty-five buildings, located less than $500 \mathrm{~m}$ from the port.

BHI's contribution will be in the center of this cluster at Medawar 479, a heritage building known as the "Blue House" for its conspicuous color. The first two floors were built in the early 1900s and the third in the 1920s. Due to its proximity to the port explosion, the building suffered great damage.

A generous grant allocated to BHI by the Honor Frost Foundation will enable the building to be fully restored with the scope of work including structural consolidation such as stone-crack stitching and anchoring of slabs, reconstruction of the pitched roof and of the north façade, repair of the cedarwood windows and doors, interior and exterior finishes such as lime plaster and paint, and mechanical, electrical, and plumbing work.

The restoration is to follow the guidelines of a thorough study commissioned by the DGA and conducted by architect-restorer Joe Kallas, who will also be a consultant on the project. A tender was launched by BHI to select an adequate contractor and works are due to start in mid October 2021.

\section{The Gholam Cluster}

Named after the family that once lived here, the Gholam Cluster is less than $1 \mathrm{~km}$ from the explosion site, with six heritage buildings. BHI is currently restoring one of these at Rmeil 722 in collaboration with another NGO, Together Li Beirut, which will be rehabilitating three other buildings in the same cluster.

Located at the junction of Gemmayzeh and Mar Mikhael, Rmeil 722 was built between 1860 and 1900, with a ground-floor commercial premises and two residential floors. As its street is aligned with the port, the building was greatly damaged.

In October $2020 \mathrm{BHI}$ covered the building's roof under a grant from ALIPH to prevent further collapse, and in April 2021, BHI was able to secure funding from multiple donors for the building's full restoration. The work is following the guidelines of a study by the BBHR architect-restorer Pierre Ghanem, commissioned by the DGA and funded by the German Archeological Institute (DAI). 
1: Rmeil 722 north facade after the blast (Dia Mrad)

2: Rmeil 722 north facade after restoration
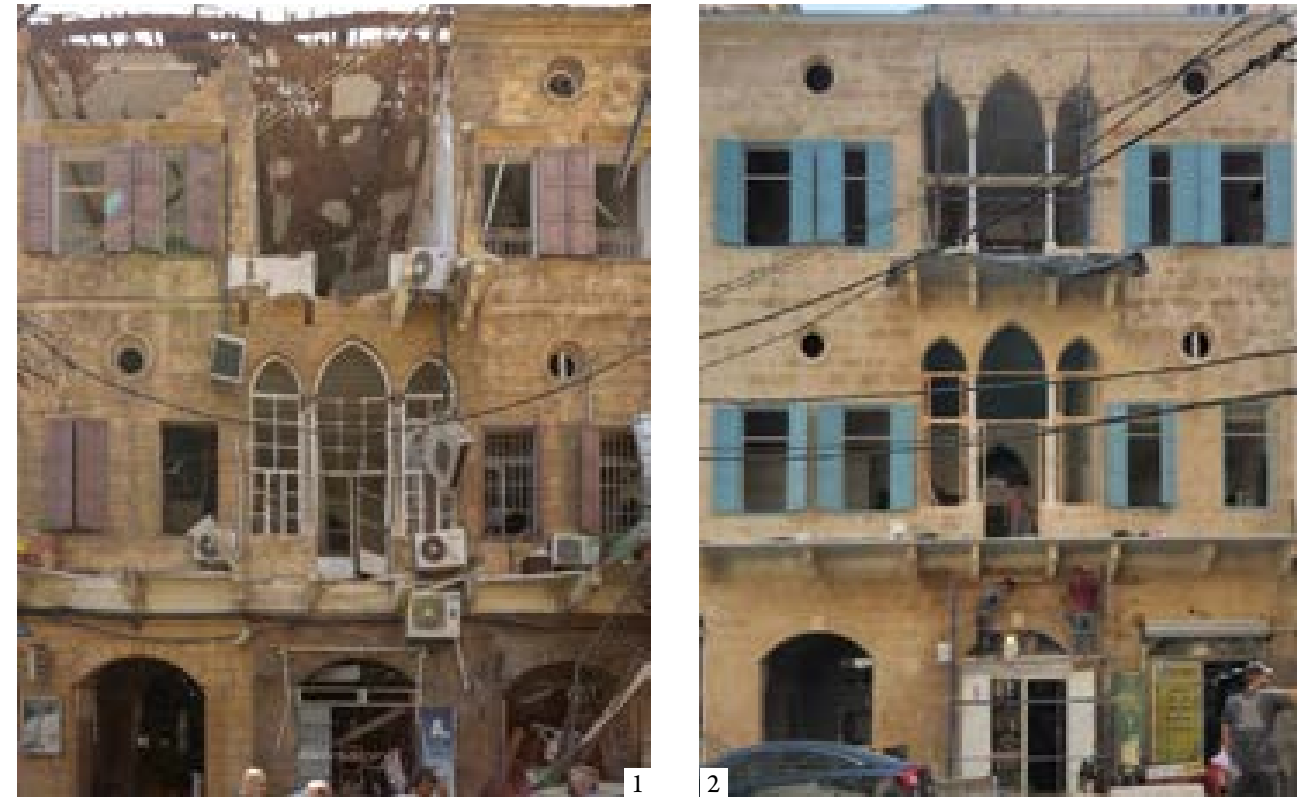

The scope of the restoration includes the dismantling and rebuilding of the sandstone north façade, the reconstruction of the qotrani pitched roof with its red clay Marseille tiles, the rebuilding of the traditional Baghdadi ceilings of wood latticework and lime plaster, the repair of the qotrani windows and doors with their original accessories, and interior and exterior lime plaster and paint finishes.

. Sorting of the dismantled trip arches on the first floor (Dia Mrad) 3: Stitching of sandstone wall cracks

4: Rejointing of the north facade stone with lime morta

5: Rehabilitation of the original wooden doors

To date, $90 \%$ of the works have been completed and the building is due to be reopened by mid October 2021.
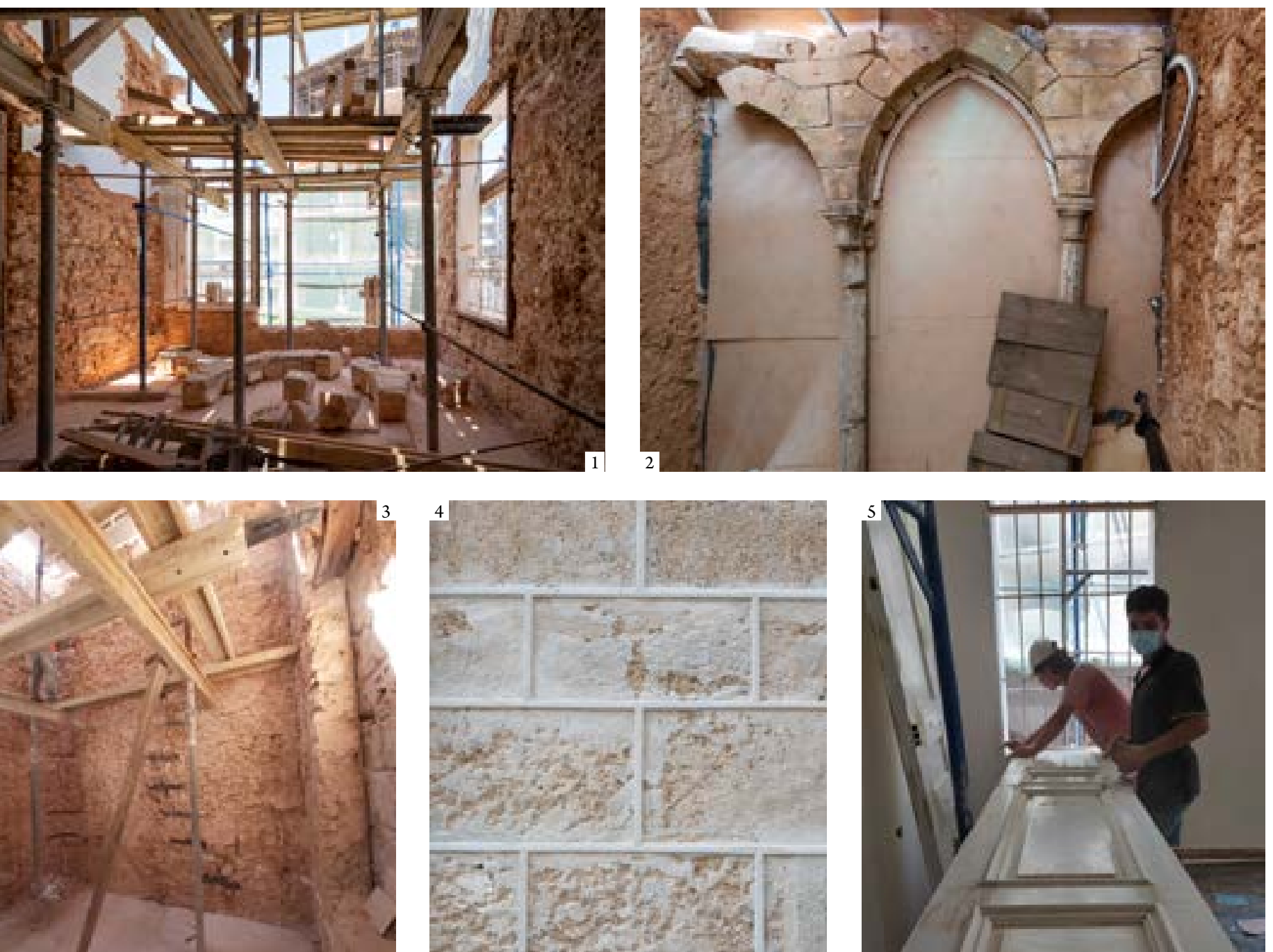


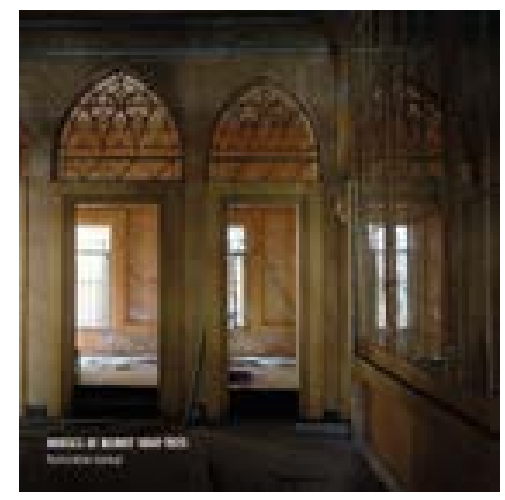

Cover of the manual Houses of Beirut 1860-1925 (Houda Kassatly)

Moreover, a grant has been allocated for the refurbishment of the Gholam public stairs within the same cluster by the French culture and ecological transition ministries.

\section{Publications and workshops}

A generous grant from Fondation de France has enabled BHI to publish two technical manuals, one on the restoration of heritage buildings built in 1860-1930 and another on buildings dating from 1930-1970. Part of the grant was also allocated to organizing seminars and courses on the restoration processes and conducting site visits and technical assessments of affected heritage buildings.

All these ventures target heritage homeowners, architects, engineers, contractors, and craftspeople involved in the restoration process. Easy access to this knowledge will facilitate the proper restoration and preservation of these damaged buildings and the inhabitants of the restored homes and businesses will be able to return and settle once again in their neighborhoods. Consequently the city, its social life, and the economic cycle will be revived.

\section{References $\mid$ Referencias $\mid$ Referências}

Assi, Naji. 2021. Introduction to Modern Heritage 1925 - 1970. https://www.youtube.com/watch?v=aoDkZz74hio\&t=995s (Consulted on 06/09/2021)

Beirut Heritage Initiative. 2021. Who we are. https://beirutheritageinitiative.com/who-we-are/ (Consulted on $06 / 10 / 2021)$

Chahine, Nathalie; and Dagher, Fadlallah (dir.). 2021. Houses of Beirut 1860 - 1925: Restoration Manual. Beirut: Al - Ayn. https://beirutheritageinitiative.com/restoration-manual/ (Consulted on 06/09/2021)

Dagher, Fadlallah. 2021a. Introduction to the Beiruti Houses 1860 - 1925. https://www.youtube.com/ watch?v=Fw3JUKMB214 (Consulted on 01/09/2021)

Dagher, Fadlallah. 2021b. Finishes: Plaster, Handrails and Flooring. https://www.youtube.com/watch?v=o8h52TblTSM (Consulted on 15/09/2021)

Jabr, Abdul-Halim. 2021. Heritage Buildings and clusters in the fabric of the City. https://www.youtube.com/ watch?v=OpA0KwHWND0 (Consulted on 05/09/2021)

\section{Biography $\mid$ Biografía | Biografia}

On behalf of Beirut Heritage Initiative:

Yasmine Elmajzoub

Yasmine holds a bachelor's degree in Architecture from the American University of Beirut. Her experiences working with architecture firms in Beirut in recent years have helped her identify and pursue an interest in heritage preservation and sustainable and participatory design. Her interest in built heritage and vernacular architecture has led her to participate in restoration and conservation workshops in Italy and Morocco, where she has been working with the NGO Terrachidia. Yasmine was involved with BHI from the start as a volunteer and currently manages its Field Operations team and projects, which she coordinates with the various stakeholders involved in restoration projects. 